\title{
Determination of Ruthenium and Osmium with Tin(II) Chloride by Second-Order Derivative Spectrophotometry
}

\author{
Maria BALCERzaK ${ }^{\dagger}$ and Stanislaw Kuś \\ Department of Analytical Chemistry, Warsaw University of Technology, Warsaw, Poland
}

\begin{abstract}
Ruthenium and osmium can be determined in the same solution by second-order derivative spectrophotometry after a conversion into complexes with tin(II) chloride. In a mixed solution containing $5 \mathrm{M}\left(1 \mathrm{M}=1 \mathrm{~mol} \mathrm{dm}^{-3}\right) \mathrm{HCl}$ and $0.05 \mathrm{M}$ $\mathrm{SnCl}_{2}$ ruthenium is quantitatively converted, from various oxidation states and various forms, into the complex $\mathrm{RuCl}_{2}\left(\mathrm{SnCl}_{3}\right)_{2}{ }^{2-}$ after heating for $45 \mathrm{~min}$. The value of the second-derivative for the anionic complex with $\mathrm{SnCl}_{3}{ }^{-}$ligands at $22250 \mathrm{~cm}^{-1}$ (zero-crossing point of osmium) is a measure of ruthenium concentration. Osmium can be determined after heating the solution containing $2 \mathrm{M} \mathrm{HCl}$ and $0.4 \mathrm{M} \mathrm{SnCl}_{2}$ for $1.5 \mathrm{~h}$. At $25900 \mathrm{~cm}^{-1}$ the value of second-derivative is dependent only on osmium concentration (zero-crossing point of ruthenium). Ruthenium, in the concentration range $2-35 \mu \mathrm{g} / \mathrm{ml}$ (in the presence up to $450 \mu \mathrm{gOs} / \mathrm{ml}$ ), and osmium, in the concentration range $7.5-90 \mu \mathrm{g} / \mathrm{ml}$ (in the presence up to $45 \mu \mathrm{gRu} / \mathrm{ml}$ ), can be determined with good precision and accuracy, without separation.
\end{abstract}

Keywords Ruthenium, osmium, noble metals analysis, derivative spectrophotometry

The separation by distillation of ruthenium and osmium, in the form of volatile $\mathrm{RuO}_{4}$ and $\mathrm{OsO}_{4}$, is usually a preliminary step in the analyses of samples of noble metals. ${ }^{1,2}$ Ruthenium(VIII) and osmium(VIII) are quantitatively absorbed in hydrochloric acid. The reduction of both the elements to lower oxidation states takes place. Depending on the reduction conditions (hydrochloric acid concentration, temperature and reaction time) ruthenium and osmium can be reduced to various oxidation states (VI, IV, III or II). ${ }^{3-5}$ In a definite oxidation state, both the metals can form complexes with different numbers of chloride, hydroxoand aqua-ligands. The compositions of the chloride complexes formed are to a large extent ${ }^{6}$ similar for ruthenium and osmium. This makes the simultaneous determination of ruthenium and osmium difficult. Generally, the separation of the two elements has to be carried out before their determination. ${ }^{1}$ There are no methods for the determination of ruthenium and osmium without their separation, especially in the form of complexes with inorganic ligands. ${ }^{1,2,7}$

Recently ${ }^{8,9}$ it has been found that ruthenium and osmium react with tin(II) chloride in hydrochloric acid medium. The metals are quantitatively converted, from higher oxidation states and various forms, into the complexes $\mathrm{RuCl}_{2}\left(\mathrm{SnCl}_{3}\right)_{2}{ }^{2-}$ and $\mathrm{OsCl}_{2}\left(\mathrm{SnCl}_{3}\right)_{2}{ }^{2-}$ containing ruthenium(II) and osmium(II). The determination of both the metals using derivative spectrophotometry after their conversion into the complexes with $\mathrm{SnCl}_{3}{ }^{-}$ligands has been described in this paper.

In the last 10 years it has been established that deriv-

\footnotetext{
† To whom correspondence should be addressed.
}

ative spectrophotometry can increase the selectivity in multicomponent inorganic analysis. ${ }^{10-17}$ The increased selectivity results from the fact that bands which overlap in normal absorption spectra appear as separated bands in the derivative spectra. The value of the derivative signal depends on the value of absorbance and on, the shape and the location of peaks in the normal (zero order) spectrum. ${ }^{11-15}$ The instrumental parameters during recording of the zero order spectra and the way of computing these spectra influence the quality of the obtained derivative signals. ${ }^{12,16,17}$ A new generation of UV-VIS spectrophotometers, equipped with suitable differentiation units, allow us to record precisely derivative spectra of various orders.

Derivative spectrophotometry sometimes enables us to remove interfering signals by handling the zero order absorption spectra. It may allow to avoid a preliminary step of components separation. This improvement in selectivity can often be obtained by using the zerocrossing measurement technique described by O'Haver and Green. ${ }^{13}$ In this technique, the derivative value is measured at the wavelength at which the interfering derivative band crosses the zero line.

In this work methods of the determination of ruthenium (in the presence of osmium) and osmium (in the presence of ruthenium) using second-order derivative spectrophotometry have been developed.

\section{Experimental}

\section{Apparatus and reagents}

The absorption spectra were recorded with a Specord 
M40 UV-VIS spectrophotometer (Carl Zeiss, Jena) with $1-\mathrm{cm}$ cells. Digitized derivative spectra were obtained with the aid of a data-handling computer cassette connected to the spectrophotometer.

Ruthenium standard solution ( $1 \mathrm{mgRu} / \mathrm{ml}$ ). Weigh exactly $100 \mathrm{mg}$ of powdered ruthenium in a silver crucible and add $1 \mathrm{~g}$ of sodium peroxide. Fuse the contents in the crucible, gradually increasing temperature to a dark red glow. Maintain the temperature for $10 \mathrm{~min}$. Allow the sample to cool, dissolve the melt in water, and acidify the solution with hydrochloric acid. Heat the mixture, filter off the coagulated $\mathrm{AgCl}$ and wash it with $0.1 \mathrm{M}\left(1 \mathrm{M}=1 \mathrm{~mol} \mathrm{dm}^{-3}\right) \mathrm{HCl}$. Transfer the filtrate into a 100-ml volumetric flask and dilute to the mark with hydrochloric acid so as to obtain the final solution $1 \mathrm{M}$ in $\mathrm{HCl}$.

Osmium standard solution (l $\mathrm{mgOs} / \mathrm{ml}$ ). Dissolve $0.2529 \mathrm{~g}$ of potassium hexachloroosmate(IV) $\left(\mathrm{K}_{2} \mathrm{OsCl}_{6}\right)$ in $100 \mathrm{ml}$ of $4 \mathrm{M} \mathrm{HCl}$.

Tin(II) chloride solution. $\quad 1 \mathrm{M} \mathrm{SnCl}_{2}$ in $2 \mathrm{M} \mathrm{HCl}$.

\section{Procedure}

Determination of ruthenium.

To the test solution containing not more than $38 \mu \mathrm{gRu} / \mathrm{ml}$ and $450 \mu \mathrm{gOs} / \mathrm{ml}$, add $0.5 \mathrm{ml}$ of $1 \mathrm{M} \mathrm{SnCl}_{2}$ and a sufficient amount of $6 \mathrm{M}$ $\mathrm{HCl}$ so as to obtain $10 \mathrm{ml}$ of the $5 \mathrm{M} \mathrm{HCl}$ solution. Heat the solution on a boiling water bath for $45 \mathrm{~min}$. Allow it to cool to room temperature. Record the absorption spectrum of the solution, using a 1-cm cell, against the reagent blank at the following instrumental parameters: wavenumber range $30303-18182 \mathrm{~cm}^{-1}(330-550 \mathrm{~nm})$; integration time INT $=2$; $S P E E D=5$; expansion of wavenumber scale EXP $X=2$. Directly obtain the second-derivative absorption spectrum of the solution; amplify the latter $(\times 40)$, then smooth it and record. Measure the value of the second derivative for ruthenium at $22250 \mathrm{~cm}^{-1}(449 \mathrm{~nm})$. Calculate the ruthenium content using an appropriate regression equation.

Determination of osmium. To the test solution $2 \mathrm{M}$ in $\mathrm{HCl}$, containing not more than $60 \mu \mathrm{gOs} / \mathrm{ml}$ and $45 \mu \mathrm{gRu} / \mathrm{ml}$, add $4 \mathrm{ml}$ of $1 \mathrm{M} \mathrm{SnCl}_{2}$ and dilute to $10 \mathrm{ml}$ with $2 \mathrm{M} \mathrm{HCl}$. Heat the solution on a boiling water bath for $1.5 \mathrm{~h}$. Allow it to cool to room temperature. Record the absorption spectrum against the reagent blank at the following instrumental parameters: 30303 $18182 \mathrm{~cm}^{-1}(330-550 \mathrm{~nm}) ;$ INT=2; SPEED $=5 ;$ EXP $\mathrm{X}=2$. Directly obtain the second-derivative absorption spectrum of the solution; amplify the latter $(\times 50)$, then smooth it and record. Measure the second derivative value for osmium at $25900 \mathrm{~cm}^{-1}(386 \mathrm{~nm})$. Calculate the content of osmium using appropriate regression equation.

\section{Results and Discussion}

In hydrochloric acid medium in the presence of tin(II) chloride, ruthenium is converted into the complex $\mathrm{RuCl}_{2}\left(\mathrm{SnCl}_{3}\right)_{2}{ }^{2-}\left(\lambda_{\max }=445 \mathrm{~nm}\right)$ (Fig. 1, curve 1). Quantitative conversion takes place in a solution $5 \mathrm{M}$ in $\mathrm{HCl}$ and

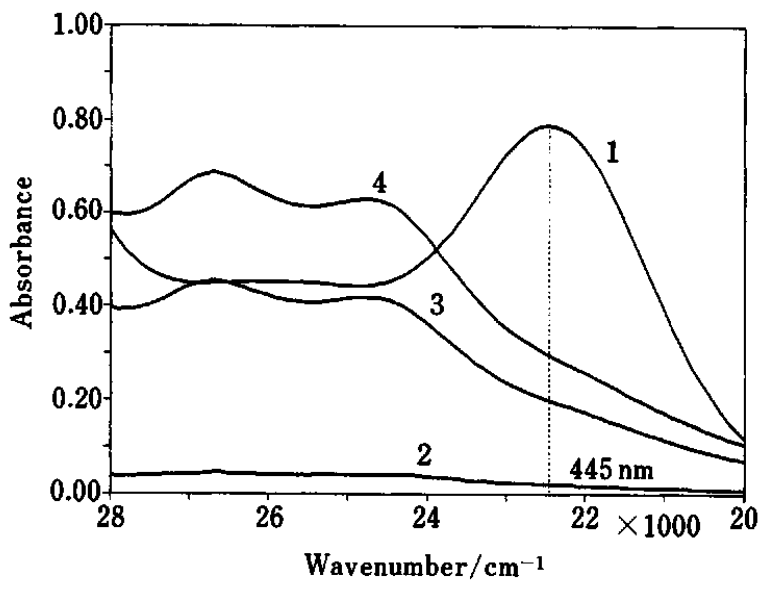

Fig. 1 Spectrum of the $\mathrm{RuCl}_{2}\left(\mathrm{SnCl}_{3}\right)_{2}{ }^{2-}$ complex $\left(c_{\mathrm{Ru}}=30 \mu \mathrm{g} /\right.$ $\mathrm{ml}$-curve 1) and spectra of osmium solutions under the same conditions as ruthenium $\left(c_{\mathrm{O}}: c_{\mathrm{Ru}}=1: 1-\right.$ curve $2 ; c_{\mathrm{Os}}: c_{\mathrm{Ru}}=$ 10:1-curve $3 ; c_{\mathrm{O}}: c_{\mathrm{Ru}}=15: 1$-curve 4$)$.
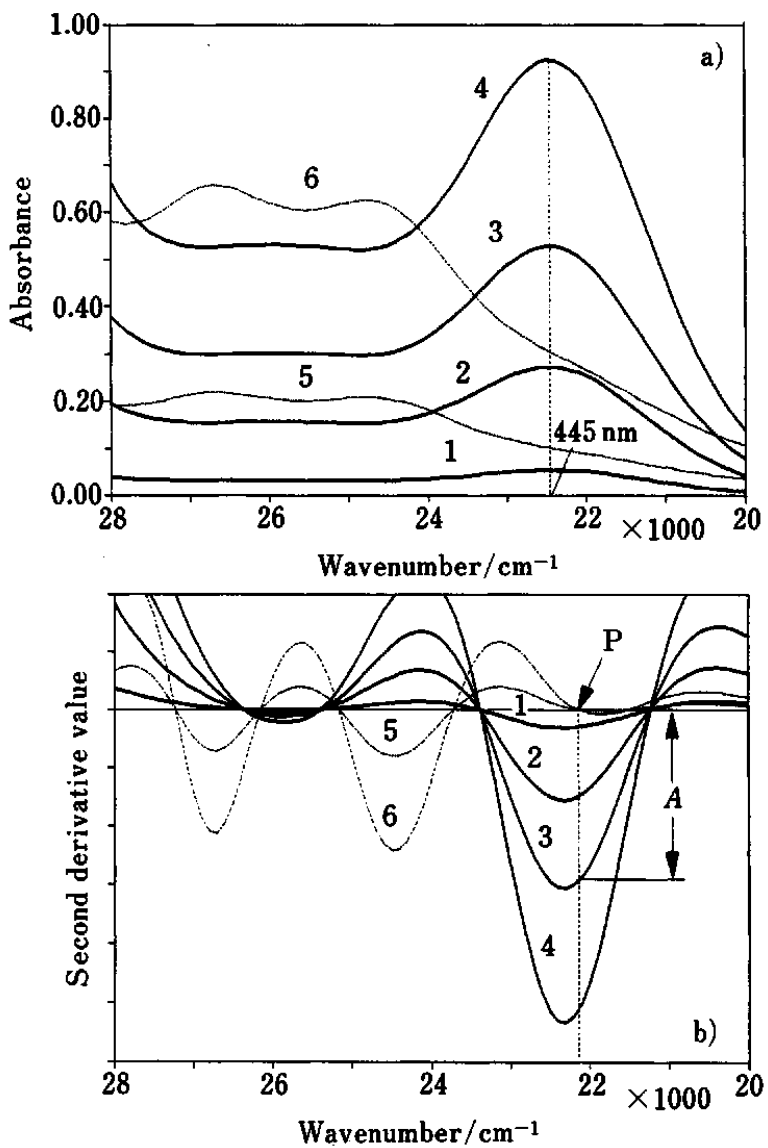

Fig. 2 Spectra (a) and second derivative spectra (b) of the $\mathrm{RuCl}_{2}\left(\mathrm{SnCl}_{3}\right)_{2}{ }^{2-}$ complex $(2 ; 10 ; 20 ; 35 \mu \mathrm{gRu} / \mathrm{ml}$-curves 1 , $2,3,4$, respectively) and osmium solutions $(150 ; 450 \mu \mathrm{gOs} /$ ml-curves 5,6 , respectively).

$0.05 \mathrm{M}$ in $\mathrm{SnCl}_{2}$ after heating on a boiling water bath for 45 min. ${ }^{8}$ The solutions of the complex obey Beer's law in the concentration range $0.5-45 \mu \mathrm{gRu} / \mathrm{ml}(l=1 \mathrm{~cm})$ $\left(\varepsilon_{445 \mathrm{~nm}}=2.7 \times 10^{3} 1 \mathrm{~mol}^{-1} \mathrm{~cm}^{-1}\right)$.

Osmium partially reacts with tin(II) chloride under the 

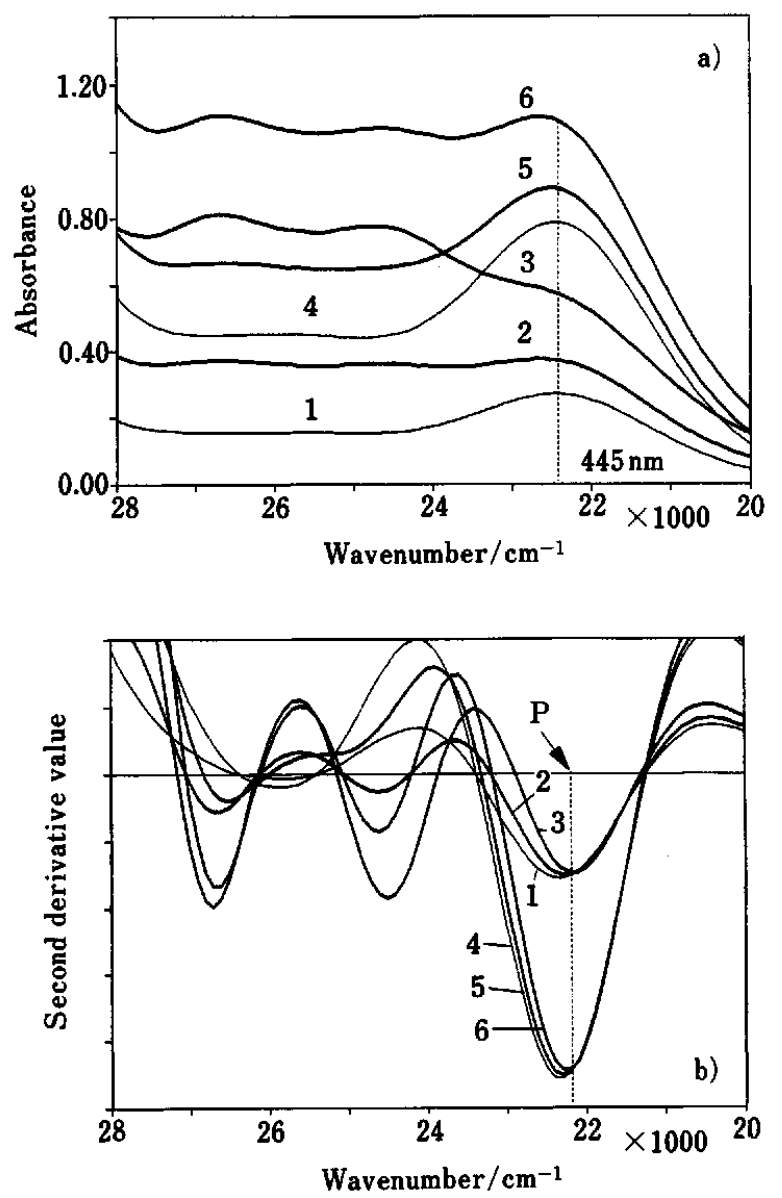

Fig. 3 Spectra (a) and second derivative spectra (b) of the ruthenium-tin(II) chloride complex $(10 \mu \mathrm{gRu} / \mathrm{ml}$-curve 1 ; $30 \mu \mathrm{gRu} / \mathrm{ml}$-curve 4) and the mixtures: $10 \mu \mathrm{gRu} / \mathrm{ml}+$ $(150 \mu \mathrm{gOs} / \mathrm{ml}$ and $450 \mu \mathrm{gOs} / \mathrm{ml}$-curves 2 and 3$) ; 30 \mu \mathrm{gRu} /$ $\mathrm{ml}+(150 \mu \mathrm{gOs} / \mathrm{ml}$ and $450 \mu \mathrm{gOs} / \mathrm{ml}$-curves 5 and 6$)$.

optimum conditions for the formation of the ruthenium complex. Simple chloride complexes of osmium are generally more stable than those of ruthenium. More drastic reduction conditions are required for quantitative reaction of osmium with tin(II) chloride. The results of the determination of ruthenium in the presence of osmium are higher by approx. $3 \%, 30 \%$ and $40 \%$ at the osmium concentration equal to that of ruthenium, 10and 15 times higher, respectively (Fig. 1, curves 2, 3 and 4). Osmium does not interfere with the determination of ruthenium (by normal spectrophotometry) up to $20 \mu \mathrm{g} / \mathrm{ml}$.

The interferences from osmium can be eliminated when second-order derivative spectrophotometry is used for recording the spectra of the ruthenium-tin(II) chloride complex. The derivative spectrum of osmium crosses the zero line at $22250 \mathrm{~cm}^{-1}(\lambda=449 \mathrm{~nm})($ point $P$ in Fig. 2b), curves 5 and 6) independently of the osmium concentration. The second derivative for the ruthenium complex has a large value at this wavelength. This value (e.g. section A, Fig. 2b)) can be a measure of ruthenium concentration. The normal and second derivative spectra containing 10 and $30 \mu \mathrm{g} / \mathrm{ml}$ of ruthenium without
Table 1 Precision of the results and the calibration graph for ruthenium determination

\begin{tabular}{rrrrrr}
\hline $\begin{array}{c}\mathrm{Ru} / \\
\mu \mathrm{g} \mathrm{ml}^{-1}\end{array}$ & Derivative value $/ \mathrm{mm}$ & $\begin{array}{r}\text { Mean/ } \\
\mathrm{mm}\end{array}$ & $\begin{array}{c}\mathrm{SD} / \\
\mathrm{mm}\end{array}$ & $\begin{array}{c}\mathrm{RSD}, \\
\%\end{array}$ \\
\hline 2 & $5.5, \quad 4.5, \quad 5.0,4.5, \quad 5.0$ & 4.9 & 0.37 & 7.64 \\
5 & $13.0,12.5,12.5,12.5,12.0$ & 12.5 & 0.32 & 2.53 \\
10 & $25.0,24.0,25.0,25.0,25.0$ & 24.8 & 0.40 & 1.61 \\
20 & $51.5,51.0,52.0,51.0,50.5$ & 51.2 & 0.51 & 1.00 \\
25 & $64.0,63.0,63.0,64.0,63.0$ & 63.4 & 0.49 & 0.77 \\
30 & $76.0,76.0,77.0,76.0,76.0$ & 76.2 & 0.40 & 0.52 \\
35 & $90.0,89.0,90.0,89.0,89.0$ & 89.4 & 0.49 & 0.55 \\
\hline
\end{tabular}

Calibration curve equation: $Y=2.559 X-0.378$, where $Y$ is the derivative value, $\mathrm{mm}$ and $X$ the concentration of $\mathrm{Ru}, \mu \mathrm{g} / \mathrm{ml}$. Correlation coefficient $r=0.99996$. Sensitivity of the method $u=0.12 \mu \mathrm{gRu} / \mathrm{ml}\left(u=s_{\mathrm{y} / \mathrm{x}} / m\right)$, where $m$ is the slope of calibration curve $(=2.559)$ and $s_{y / x}$ the average deviation from the regression line ${ }^{16}$ defined as $s_{\mathrm{y} / \mathrm{x}}=\left[\left(\sum_{i=1}^{n}\left(\hat{y}_{i}-y_{i}\right)^{2}\right) /(n-2)\right]^{1 / 2}(\hat{y}$, derivative value calculated for a given concentration $x_{i} ; y_{i}$, experimental derivative value for given $x_{i}$ ).

and with addition of osmium (150 and $450 \mu \mathrm{g} / \mathrm{ml})$ are shown in Figs. 3a) and 3b).

The equation of the calibration graph for the determination of ruthenium has been obtained on the basis of the value of the second derivative for ruthenium, at $22250 \mathrm{~cm}^{-1}$, at various concentrations of this metal (Table 1). The relative standard deviation (RSD) of the determination of ruthenium in the concentration range $2-35 \mu \mathrm{g} / \mathrm{ml}$ equals $7.64-0.55 \%$.

Osmium is quantitatively converted into the complex $\mathrm{OsCl}_{2}\left(\mathrm{SnCl}_{3}\right)_{2}{ }^{2-}\left(\lambda_{\max }=385 \mathrm{~nm}\right)$ (Fig. 4, curve 1) in the medium $2 \mathrm{M}$ in $\mathrm{HCl}$ and $0.4 \mathrm{M}$ in $\mathrm{SnCl}_{2}$ after heating on a boiling water bath for $1.5 \mathrm{~h} .{ }^{9}$ The obtained complex obeys Beer's law in the concentration range $1-90 \mu \mathrm{gOs} /$ $\mathrm{ml}(l=1 \mathrm{~cm})\left(\varepsilon_{385 \mathrm{~min}}=2.4 \times 10^{3} 1 \mathrm{~mol}^{-1} \mathrm{~cm}^{-1}\right)$.

Ruthenium influences to large extent the determination of osmium with tin(II) chloride (Fig. 4, curve 2). At equal concentrations of both the metals in the examined solutions, the results of the determination of osmium are

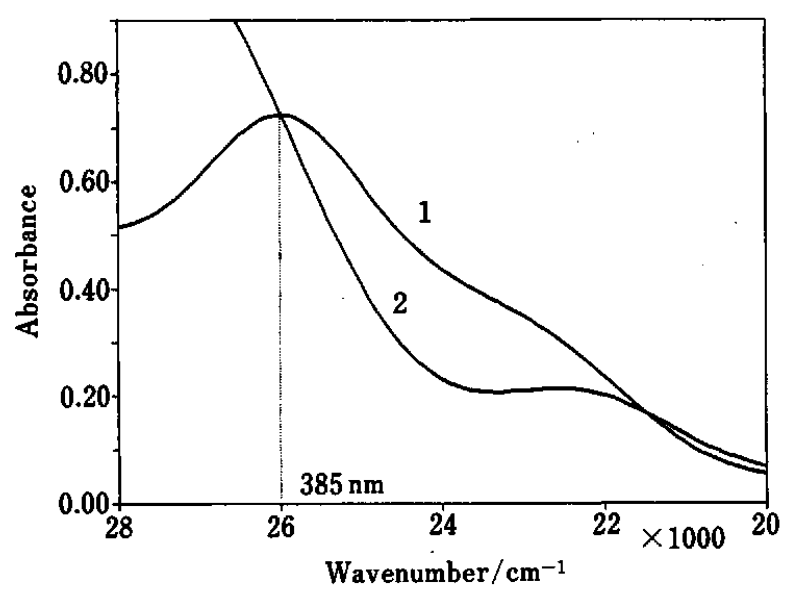

Fig. 4 Spectra of the osmium-tin(II) chloride complex (curve 1) and ruthenium under the same conditions as osmium (curve 2) $\left(c_{\mathrm{Os}}=c_{\mathrm{Ru}}=60 \mu \mathrm{g} / \mathrm{ml}\right)$. 

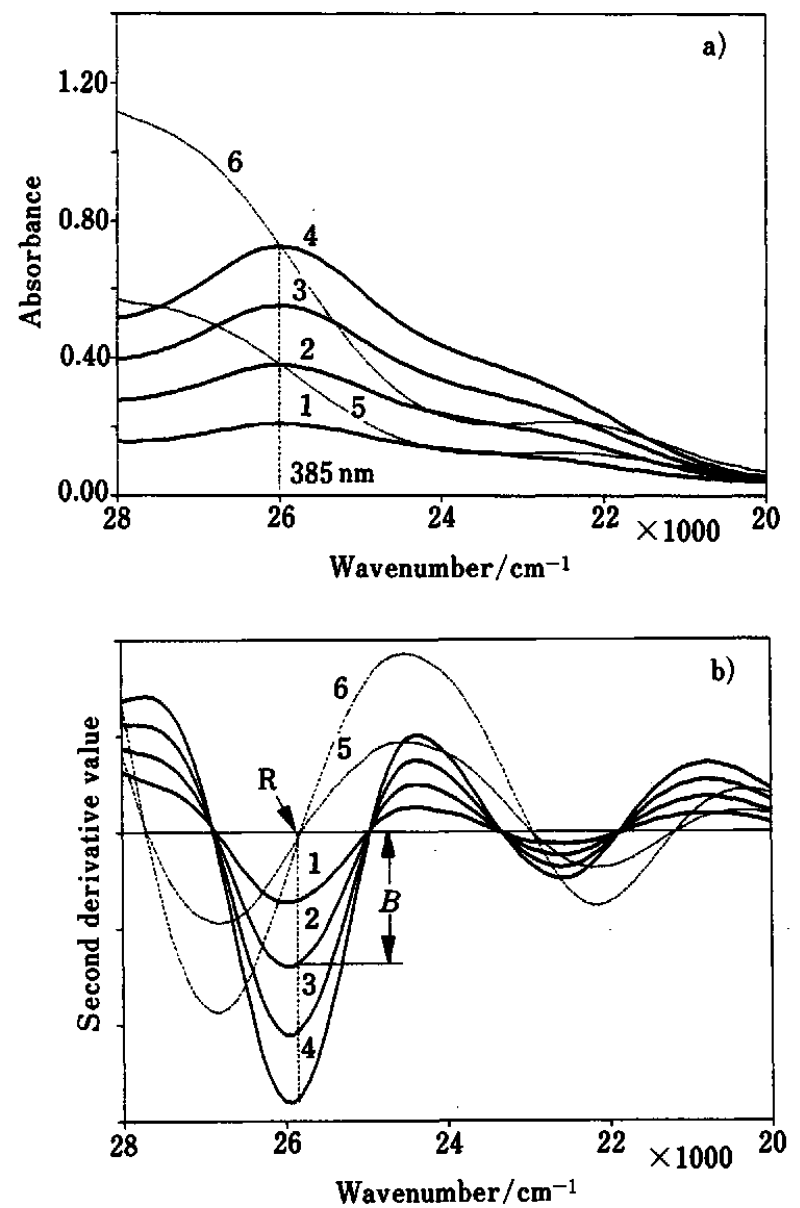

Fig. 5 Spectra (a) and second derivative spectra (b) of the $\mathrm{OsCl}_{2}\left(\mathrm{SnCl}_{3}\right)_{2^{2-}}$ complex $(15 ; 30 ; 45 ; 60 \mu \mathrm{gOs} / \mathrm{ml}$-curves 1 , $2,3,4$, respectively) and ruthenium solutions $(15 ; 30 \mu \mathrm{gRu} /$ ml-curves 5,6 , respectively).

two times higher. The increase in the tin(II) chloride concentration (from $0.05 \mathrm{M}$ to $0.4 \mathrm{M}$ ) and heating time (from $45 \mathrm{~min}$ to $1.5 \mathrm{~h}$ ) leads to the further reduction of $\mathrm{Ru}^{\mathrm{II}}$ and partial decomposition of the $\mathrm{RuCl}_{2}\left(\mathrm{SnCl}_{3}\right)_{2}{ }^{2-}$ complex. The spectrum of the ruthenium complex changes to a large extent. The maximum absorbance at $445 \mathrm{~nm}$ rapidly decreases and the absorption band in the UV region rapidly increases.

No interferences of ruthenium in the determination of osmium are observed when second derivative spectra of the examined solutions are recorded. The second derivative for ruthenium crosses the zero line at $25900 \mathrm{~cm}^{-1}(\lambda=386 \mathrm{~nm})$, point $R$ in Fig. $\left.5 b\right)$, curves 5 and 6. The distance of the second derivative for osmium and the zero line at the zero-crossing point of ruthenium (e.g. dimension B at Fig. 5b)) is a measure of osmium concentration.

The normal and second derivative spectra of the solutions containing 15 and $60 \mu \mathrm{g} / \mathrm{ml}$ of osmium without and with addition of 20 and $40 \mu \mathrm{g} / \mathrm{ml}$ of ruthenium are shown in Fig. 6. The derivative value for osmium at $25900 \mathrm{~cm}^{-1}$ is dependent only on osmium concentration in the examined solution.

The second derivative values for osmium (in the con-
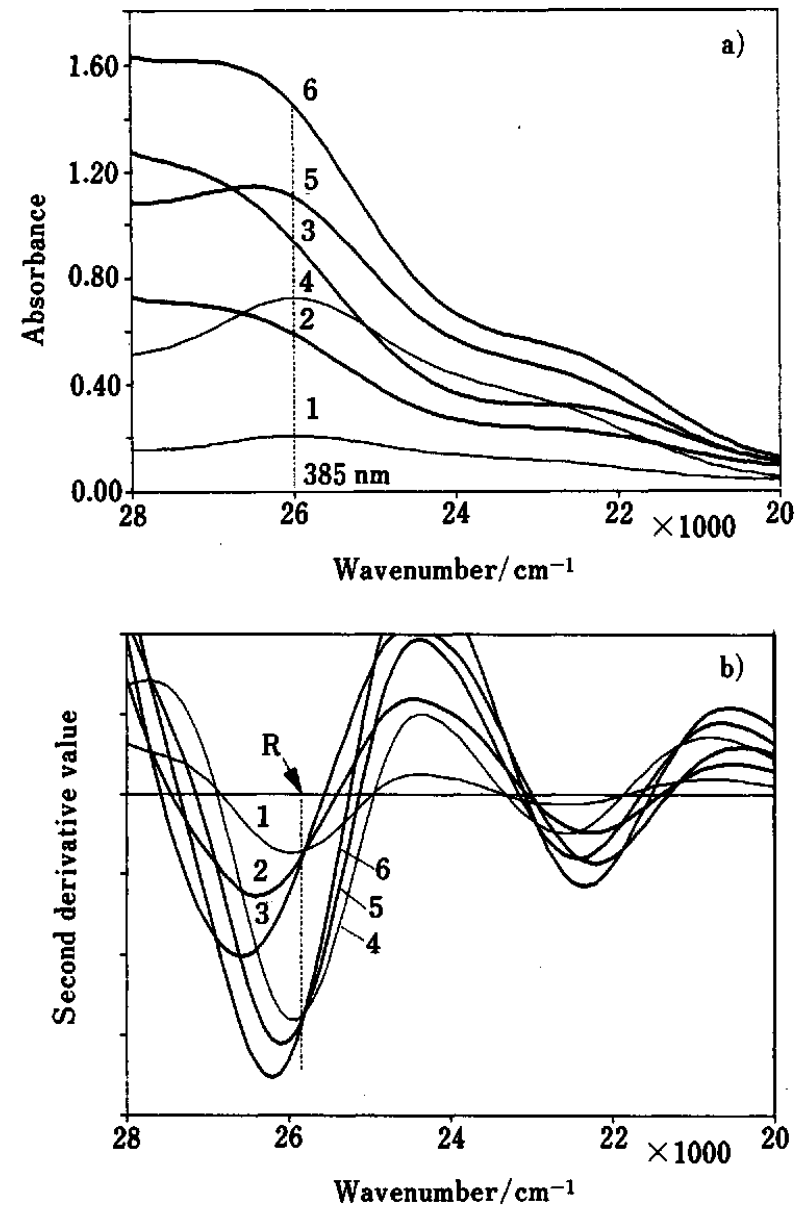

Fig. 6 Spectra (a) and second derivative spectra (b) of osmium-tin(II) chloride complex $(15 \mu \mathrm{gOs} / \mathrm{ml}$-curve 1 ; $60 \mu \mathrm{gOs} / \mathrm{ml}-$ curve 4) and the mixtures: $15 \mu \mathrm{gOs} / \mathrm{ml}+$ $(20 \mu \mathrm{gRu} / \mathrm{ml}$ and $40 \mu \mathrm{gRu} / \mathrm{ml}$-curves 2 and 3); $60 \mu \mathrm{gOs} /$ $\mathrm{ml}+(20 \mu \mathrm{gRu} / \mathrm{ml}$ and $40 \mu \mathrm{gRu} / \mathrm{ml}$-curves 5 and 6$)$.

Table 2 Precision of the results and the calibration graph for osmium determination

\begin{tabular}{ccrrrc}
\hline $\begin{array}{c}\text { Os/ } \\
\mu \mathrm{g} \mathrm{ml}^{-1}\end{array}$ & Derivative value/mm & $\begin{array}{c}\text { Mean/ } \\
\mathrm{mm}\end{array}$ & $\begin{array}{c}\text { SD/ } \\
\mathrm{mm}\end{array}$ & $\begin{array}{c}\text { RSD, } \\
\%\end{array}$ \\
\hline 7.5 & $6.5,7.0,7.0,7.5,7.5$ & 7.1 & 0.37 & 5.27 \\
15 & $13.5,13.5,13.5,13.0,13.0$ & 13.3 & 0.24 & 1.84 \\
30 & $28.0,28.0,28.0,27.5,29.0$ & 28.1 & 0.49 & 1.74 \\
45 & $44.0,43.0,43.5,42.5,43.0$ & 43.2 & 0.51 & 1.18 \\
60 & $58.5,57.5,58.0,57.5,58.0$ & 57.9 & 0.37 & 0.65 \\
75 & $74.5,73.0,73.0,71.0,74.0$ & 73.1 & 1.20 & 1.64 \\
90 & $88.0,87.0,90.5,88.0,89.0$ & 88.5 & 1.18 & 1.34 \\
\hline
\end{tabular}

Calibration curve equation: $Y=0.991 X-1.213$. Correlation coefficient $r=0.99987$; sensitivity of the method $u=0.55 \mu \mathrm{gOs} /$ ml.

centration range of $7.5-90 \mu \mathrm{gOs} / \mathrm{ml}$ ) at zero-crossing point of ruthenium $\left(25900 \mathrm{~cm}^{-1}\right)$ are the basis of the equation for the calibration graph. The data given in Table 2 point to the good precision of the results. 
Table 3 The results of the determination of osmium and ruthenium in waste solution

\begin{tabular}{|c|c|c|c|c|c|c|}
\hline \multirow{2}{*}{ Sample examined $/ \mathrm{ml}$} & \multicolumn{2}{|c|}{$\mathrm{Ru}$} & \multicolumn{2}{|l|}{ Os } & \multicolumn{2}{|c|}{ Content $/ \mathrm{Hg} \mathrm{ml}^{-1}$} \\
\hline & Deriv. value/mm & Found $/ \mu \mathrm{g}$ & Deriv. value/mm & Found/ $\mu \mathrm{g}$ & $\mathbf{R u}$ & Os \\
\hline 5 & 7.5 & 30.8 & 8.5 & 103.6 & 12.3 & 41.4 \\
\hline 5 & 8.0 & 32.7 & 9.5 & 113.6 & 13.1 & 45.4 \\
\hline 10 & 14.0 & 56.2 & 20.0 & 218.7 & 11.2 & 43.7 \\
\hline 10 & 15.0 & 60.1 & 19.5 & 213.7 & 12.0 & 42.7 \\
\hline 20 & 34.5 & 136.3 & 40.0 & 419.0 & 13.6 & 41.9 \\
\hline \multirow[t]{4}{*}{20} & 34.0 & 134.3 & 37.0 & 389.0 & 13.4 & 38.9 \\
\hline & & & \multicolumn{2}{|c|}{$\operatorname{Mean}(\mu \mathrm{g} / \mathrm{ml})$} & 12.6 & 42.4 \\
\hline & & & \multicolumn{2}{|c|}{$\mathrm{SD}(\mu \mathrm{g} / \mathrm{ml})$} & 0.8 & 2.0 \\
\hline & & & \multicolumn{2}{|c|}{$\operatorname{RSD}(\%)$} & 6.7 & 4.8 \\
\hline
\end{tabular}

\section{Analytical Application}

The developed methods of second order derivative spectrophotometry were applied to the determination of ruthenium and osmium in a waste solution containing both the metals and tin(II) chloride. Ruthenium and osmium were separated from the examined solution in the forms of $\mathrm{RuO}_{4}$ and $\mathrm{OsO}_{4}$ by distillation from $\mathrm{HClO}_{4}+\mathrm{H}_{2} \mathrm{SO}_{4}(1+3)$ medium. Both tetroxides were absorbed in two receivers containing 5 and $4 \mathrm{ml}$ of $2 \mathrm{M}$ $\mathrm{HCl}$. The distillation apparatus was purged with nitrogen (at the flow rate of $2-3$ bubbles per second). The distillation was carried out until intense fumes of $\mathrm{HClO}_{4}$ appeared in the distillation flask. The contents of the receivers were transfered into a $10-\mathrm{ml}$ flask and diluted to the mark with $2 \mathrm{M} \mathrm{HCl}$. Ruthenium (or osmium) content was determined in half a volume of the obtained solution according to the procedures described above. The results are shown in Table 3. The relative standard deviations (RSD) for the concentration of ruthenium $(12.6 \mu \mathrm{g} / \mathrm{ml})$ and osmium $(42.4 \mu \mathrm{g} / \mathrm{ml})$ determined equal to $6.7 \%$ and $4.8 \%$, respectively.

\section{References}

1. F. E. Beamish and J. C. Van Loon, "Recent Advances in the Analytical Chemistry of the Noble Metals", Pergamon Press, Oxford, 1972.

2. S. I. Ginsburg, N. A. Ezerskaya, I. V. Prokof'eva, N. F. Fedorenko, V. I. Shlenskaya and N. K. Belskii,
"Analytical Chemistry of Platinum Metals", Izd. Nauka, Moscov, 1972.

3. M. Balcerzak, Mikrochim. Acta [Wien], 1985 II, 389.

4. I. P. Alimarin, V. P. Khvostova and G. I. Kadyrova, $Z h$. Anal. Khim., 30, 2007 (1975).

5. Z. Marczenko, M. Balcerzak and H. Pasek, Mikrochim. Acta [Wien], 1982 II, 371.

6. S. E. Livingstone, "The Chemistry of Ruthenium, Rhodium, Palladium, Osmium, Iridium and Platinum", Pergamon Press, Oxford, 1973.

7. Z. Marczenko, "Separation and Spectrophotometric Determination of Elements", Ellis Horwood, Chichester, 1986.

8. M. Balcerzak and W. Woźniak, Microchem. J., 37, 326, 1988.

9. M. Balcerzak, Analyst [London], 113, 129 (1988).

10. R.Lobinski and Z. Marczenko, Crit. Rev. Anal. Chem., 23, 55 (1992).

11. G. Talsky, L. Mayring and H. Kreuzer, Angew. Chem., 90, 840 (1978).

12. H. Ishii and K. Satoh, Fresenius' Z. Anal. Chem., 312, 114 (1982).

13. T. C. O'Haver and G. L. Green, Anal. Chem., 48, 312 (1976).

14. P. Levillain and D. Fompeydie, Analusis, 14, 1 (1986).

15. G. Talsky, Fresenius' Z. Anal. Chem., 333, 702 (1989).

16. S. Kuś and Z. Marczenko, Talanta, 36, 1139 (1989).

17. S. Kuś, N. Obarski and Z. Marczenko, Anal. Sci., 8, 213 (1992).

18. J. C. Miller and J. N. Miller, "Statistics for Analytical Chemistry", Ellis Horwood, Chichester, 1984.

(Received June 14, 1993) (Accepted December 15, 1993) 